\title{
STRATEGI PENGEMBANGAN BISNIS TAMBAK IKAN BANDENG DI DESA MENGARE WATUAGUNG GRESIK
}

\author{
Ersa Nanda Aulia \\ Magister Manajemen, Universitas Airlangga, Surabaya, Indonesia \\ Email: ersanandaaulia@gmail.com
}

\begin{abstract}
This research was conducted to analyze the factual conditions in the milkfish pond business, find out the development business strategy, and compile a business plan for milkfish pond business development. This study uses data analysis methods in the form of in-depth interviews, observation and documentation. From the results of the research the factual business conditions on the technical aspects including pond preparation, fertilizing and eradicating pests, acclimatization and spreading nener, feeding, and harvesting have been going well. In the management aspect which consists of planning, organizing, moving, and supervising according to business functions. In the marketing aspects including marketing mix, marketing channels, marketing margins and ways of payment have been distributed to consumers. In the calculation of short-term and long-term financial aspects it can be concluded that this business is profitable and feasible to run financially. The business development strategy with the SWOT analysis is located in quadrant I, which supports aggressive growth policies using the SO (Strength Opportunities) strategy. The strategy used is to maintain the quality of milkfish, conduct training with field extension workers, utilize natural resources, facilities and infrastructure to support business and optimize this business for the better by looking at financial aspects that are viable.
\end{abstract}

Keywords: Strategy, Feasibility, SWOT, Milkfish Pond Business

\begin{abstract}
ABSTRAK
Penelitian ini dilakukan untuk menganalisis kondisi faktual pada bisnis tambak ikan bandeng, mengetahui strategi pengembangan bisnis, dan menyusun perencanaan bisnis pengembangan usaha tambak ikan bandeng Penelitian ini menggunakan metode analisis data berupa wawancara mendalam (in-depth interview), observasi serta dokumentasi. Dari hasil penelitian kondisi faktual bisnis pada aspek teknis meliputi persiapan tambak, pemupukan dan pemberantasan hama, aklimatisasi dan penebaran nener, pemberian pakan, serta pemanenan telah berjalan dengan baik. Pada aspek manajemen yang terdiri dari perencanaan, pengorganisasian, pergerakan, dan pengawasan telah berjalan sesuai dengan fungsi bisnis. Pada aspek pemasaran meliputi bauran pemasaran, saluran pemasaran, margin pemasaran dan cara pembayaran telah terdistribusi kepada konsumen. Pada perhitungan aspek finansiil jangka pendek dan jangka panjang dapat disimpulkan bahwa bisnis ini menguntungkan dan layak untuk dijalankan secara finansiil. Strategi pengembangan bisnis dengan analisis SWOTterletak di kuadran I, yaitu mendukung kebijakan pertumbuhan yang agresif dengan menggunakan strategi SO (Strength Opportunities). Strategi yang digunakan adalah mempertahankan kualitas ikan bandeng, mengadakan pelatihan dengan petugas penyuluh lapang, memanfaatkan sumberdaya alam, sarana dan prasarana untuk mendukung bisnis serta mengoptimalkan usaha ini menjadi lebih baik dengan melihat dari aspek finansiil yang layak.
\end{abstract}

Kata Kunci: Strategi, Kelayakan Bisnis, SWOT, Bisnis Tambak Ikan Bandeng 


\section{PENDAHULUAN}

Budidaya tambak hingga sekarang terhitung sebagai suatu usaha yang dapat memberikan pendapatan yang luar biasa. Kecenderungan kearah ini memang beralasan karena terbukti pada lahan - lahan yang baru dibuka ternyata dapat menghasilkan produksi, baik pada tingkat penguasaan teknologi pembudidaya yang masih rendah hingga sedang. Beberapa komoditas perikanan hasil budidaya tambak yang sangat potensial dan memiliki prospek untuk dikembangkan sebagai komoditas ekspor unggulan guna memberikan kontribusi terhadap peningkatan taraf hidup masyarakat seperti ikan bandeng, dan ikan nila (Ashari, 2012).

Menurut Maulana (2008), Bandeng merupakan salah satu komoditas perikanan yang biasa dikonsumsi oleh masyarakat. Ikan bandeng memiliki kelebihan diantaranya kandungan protein yang cukup tinggi, rasanya yang gurih dan netral, harga yang relatif terjangkau dan tidak mudah hancur ketika dimasak. Ikan bandeng memiliki tingkat atau kadar protein yang cukup tinggi yaitu sekitar 20 gram (per 100 gram). Oleh sebab itu, banyak pembudidaya atau pembisnis yang terjun langsung untuk membudidayakan ikan bandeng dan mengomersilkannya.

Menurut Rangka dan Asaad (2010), budidaya ikan bandeng (Chanos chanos) di tambak telah berkembang secara pesat hampir di seluruh Indonesia dengan memanfaatkan perairan payau atau pasang surut. Aplikasi teknologi budidaya bendeng meliputi teknologi budidaya secara tradisional hingga intensif. Berbagai opsi budidaya bandeng dapat dilakukan di Keramba Jaring Apung (KJA) dengan memanfaatkan sifat biologis ikan bandeng yang didromus dan budidaya di tambak air payau yang dapat dikombinasikan dengan komoditas lainnya (polikultur). Penentuan lokasi tambak perlu didukung dengan memperhatikan aspek teknis dan non teknis. Pengembangan usaha perikanan budidaya sangat tergantung kepada ketersediaan induk unggul dan benih berkualitas.

Pengembangan usaha Perikanan Budidaya bertujuan untuk mengetahui gambaran secara jelas modal atau investasi yang diperlukan untuk operasional suatu usaha kegiatan produksi tambak per musim tanam atau dalam satu tahun. Secara garis besar petani atau pelaku usaha perikanan dapat mengetahui penerimaan dan keuntungan yang diperoleh serta beberapa lama kemungkinan modal investasi tersebut dapat dikembalikan (Adi, 2011).

Kabupaten Gresik merupakan salah satu penghasil ikan bandeng di Jawa Timur karena dilihat dari potensi perikanan yang cukup besar maka di daerah ini cocok untuk mengembangkan bisnis tambak ikan bandeng. Adanya pengembangan usaha di daerah ini akan memberikan dampak positif terhadap perekonomian dan kesejahteraan masyarakat sekitar, selain itu dapat membuka lapangan pekerjaan di daerah tersebut sehingga dapat menyerap tenaga kerja pada masyarakat sekitar untuk pebisnis tambak ikan bandeng. Maka dengan adanya bisnis tambak ikan bandeng ini akan meningkatkan perekonomian dan kesejahteraan masyarakat di Desa Mengare Watuagung.

Peningkatan kebutuhan ikan bandeng setiap tahunnya tentu diikuti dengan meningkatnya produksi ikan bandeng. Kabupaten Gresik merupakan salah satu wilayah penyuplai ikan terbesar di Jawa Timur. Luas area tambak budidaya ikan di Kabupaten Gresik mencapai $32.000 \mathrm{Ha}$, atau sekitar 46\% dari total luas area tambak di Jawa Timur. Hasil produksi budidaya mencapai 100.027 ton per tahun. Area tambak yang cukup besar ini membuat Kabupaten Gresik sangat potensial untuk budidaya yang nantinya akan turut membantu mengurangi tingkat pengangguran dan meningkatkan perekonomian masyarakat, khususnya masyarakat Kabupaten Gresik yang tinggal di wilayah pesisir.

Kondisi tambak di Desa Mengare Watuagung Gresik saat ini dihadapkan pada masalah yang cukup krusial dalam beberapa tahun terakhir, yaitu masalah penurunan produksiyang di tampilkan pada Tabel 1. Bisnis ikan bandeng ini merupakan bisnis keluarga yang dijalankan seperti biasa tanpa adanya persiapan dan perencanaan yang matang. Bisnis ini perlu dilakukan strategi pengembangan dengan melihat kondisi internal dan eksternal yang ada pada bisnis sehingga penurunan produksi ini tidak akan berlanjut ke tahun tahun yang akan datang.

Tabel 1

Jumlah Produksi pada Bisnis Ikan Bandeng

\begin{tabular}{|c|c|c|}
\hline No. & \multicolumn{1}{|c|}{ Tahun } & Jumlah Produksi $(\mathrm{Kg})$ \\
\hline 1. & 2016 & 20.000 \\
\hline 2. & 2017 & 18.750 \\
\hline 3. & 2018 & 18.000 \\
\hline
\end{tabular}


Melihat dari referensi diatas dapat disimpulkan bahwa bisnis tambak ikan bandeng mudah untuk dijalankan dan tidak memerlukan biaya yang mahal. Ikan bandeng sangatlah mudah untuk dibudidayakan, maka dari itu diperlukan adanya suatu penelitian lebih lanjut mengenai aspek teknis, aspek manajemen, aspek pemasaran, aspek finansiil, strategi pengembangan usaha, dan perencanaan bisnis pengembangan bisnis tambak ikan bandeng yang bertujuan untuk meningkatkan kualitas ikan bandeng, meningkatkan pendapatan masyarakat, dan mengetahui usaha pengembangan bisnis ikan bandeng di Desa Mengare Watuagung Gresik layak dijalankan.

\section{Rumusan Masalah}

Berdasarkan latar belakang penelitian, maka usaha tersebut dapat dikembangkan dengan rumusan masalah sebagai berikut:

1. Bagaimana kegiatan bisnis tambak ikan bandeng dilaksanakan?

2. Bagaimana strategi pengembangan bisnis tambak ikan bandeng?

3. Bagaimana perencanaan pengembangan bisnis tambak ikan bandeng berdasarkan aspek manajemen, aspek pemasaran, dan aspek finansiil?

\section{KAJIAN PUSTAKA \\ Strategi}

Strategi adalah serangkaian terpadu dan terkoordinasi dari komitmen dan tindakan yang dirancang untuk mengeksploitasi kompetensi inti dan mendapatkan keunggulan bersaing. Ketika memilih strategi, perusahaan membuat pilihan diantara alternatif bersaing sebagai jalur untuk memutuskan bagaimana mereka akan mengejar daya saing strategis. Dalam hal ini, strategi yang dipilih menunjukkan apa yang akan dilakukan perusahaan dan apa yang tidak akan dilakukan perusahaan (Hitt et al., 2017).

\section{Bisnis Tambak Ikan Bandeng}

Dalam bisnis pembudidayaan ikan, lingkungan perairan yang cukup luas merupakan nilai lebih yang dimiliki Indonesia. Dalam hal ini, peningkatan budidaya ikan bandeng biasa dijadikan alternatif upaya pemenuhan gizi dan pangan serta upaya peningkatan taraf hidup masyarakat. Ikan bandeng merupakan salah satu komoditas perikanan yang dianggap bernilai ekonomis tinggi, sehingga sangat potensial untuk dibudidayakan secara optimal. Untuk menggali potensial tersebut, dibutuhkan pemahaman mengenai ikan bandeng dan seluk beluknya (Muntalim, 2014).

\section{Kelayakan Bisnis}

Studi kelayakan bisnis adalah suatu studi yang dilakukan secara mendalam serta seksama tentang berbagai aktivitas yang akan dikerahkan di masa akan datang untuk melihat atau mengetahui tingkat kelayakan laba yang diperoleh (Kasmir dan Jakfar, 2012).

Menurut Johan (2011), Aspek teknis atau biasa disebut dengan aspek produksi wajib dipertimbangkan dalam studi kelayakan bisnis. Aspek ini akan ditentukan oleh sistem produksi maupun sumberdaya yang perlu diinvestasikan seperti bahan baku, lokasi, lay out, dan teknologi yang dipakai. Teknologi yang digunakan juga ditentukan dalam aspek ini, mengingat teknologi ikut menentukan kompetitif atau tidaknya sebuah produk atau jasa yang dihasilkan.

\section{Perencanaan Bisnis}

Perencanaan bisnis merupakan langkah awal dalam menjalankan bisnis, biasanya terdiri dari apa yang akan dilakukan, kapan dan bagaimana cara melakukannya. Perencanaan bisnis yang baik akan membantu dalam melihat lebih jelas mengenai tipe bisnis yang dirintis, siapa saja yang akan menjadi konsumen dan produk apa saja yang akan ditawarkan (Arif, 2008)

Perencanaan bisnis adalah alat yang digunakan utuk mencari dana dari pihak ketiga. Beberapa hal yang harus ada di dalam perencanaan bisnis antara lain penjelasan mengenai bisnis yang sedang di geluti dan rencana yang bersifat strategis, rencana rencana pemasaran, rencana manajemen keuangan dan rencana manajemen operasional (Rangkuti, 2008). Perencanaan bisnis yang dibuat untuk mengembangkan usaha pembesaran ikan bandeng meliputi aspek manajemen, aspek pemasaran dan aspek finansiil.

\section{METODE PENELITIAN}

Metode penelitian yang digunakan yaitu metode penelitian deskriptif, dengan mempelajari permasalahan dari obyek yang diteliti, sehingga diketahui faktor - faktor strategik yang berpengaruh dalam pengembangan bisnis ikan bandeng di Desa Mengare Watuagung Gresik. Selain itu, metode deskriptif digunakan untuk memperoleh 
gambaran informasi, penjelasan, dan kondisi yang berkaitan dengan obyek penelitian.

Metode deskriptif ini dijalankan dengan melakukan in-depth interview yang dilakukan saat peneliti memerlukan informasi yang bersifat mendalam dan detail dari informan, selain itu peneliti juga bisa melakukan wawancara saat ingin menggali emosi, pengalaman dan perasaan informan. Untuk mencatat hal yang penting maka peneliti bisa menggunakan catatan lapangan yang berfungsi sebagai catatan pendukung akan hal hal penting yang terjadi selama proses wawancara berlangsung atau segera setelah wawancara berakhir (Denscombe, 2003).

Wawancara yang dilakukan dalam kegiatan penelitian pada usaha pembesaran ikan bandeng meliputi aspek teknis, aspek manajemen, aspek pemasaran, aspek finansiil, faktor penghambat dan faktor pendukung pada usaha pembesaran ikan bandeng di tambak.

Menurut Akbar dan Usman (2009), observasi ialah pengamatan dan pencatatan yang sistematis terhadap gejala - gejala yang diteliti. Observasi menjadi salah satu teknik pengumpulan data apabila sesuai dengan tujuan penelitian, direncanakan dan dicatat secara sistematis, serta dapat dikontrol keandalan (reliabilitas) dan kesalahannya (validitasnya).

Observasi yang dilakukan dalam kegiatan penelitian pada usaha pembesaran ikan bandeng meliputi kegiatan sebagai berikut :

1. Bentuk, kontruksi dan peralatan - peralatan yang digunakan dalam kegiatan pembesaran ikan bandeng

2. Kegiatan usaha pembesaran ikan bandeng yang meliputi kegiatan persiapan tambak hingga pemanenan

3. Kondisi lingkungan sosial masyarakat Desa Mengare Watuagung dengan adanya usaha pembesaran ikan bandeng.

Menurut Soehartono (2011), Dokumentasi merupakan teknik pengumpulan data secara tidak langsung ditujukan kepada subjek penelitian. Dokumen yang diteliti dapat berupa berbagai macam, tidak hanya dokumen resmi.

Dokumentasi yang dilakukan dalam kegiatan penelitian pada bisnis tambak ikan bandeng berupa foto tentang aktivitas bisnis.
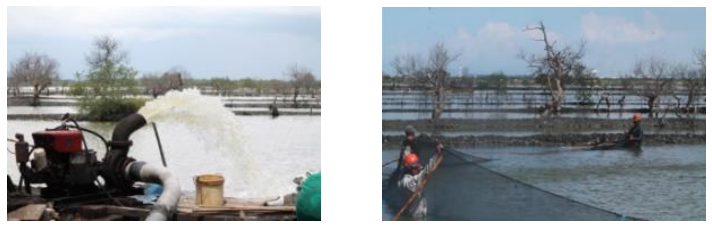
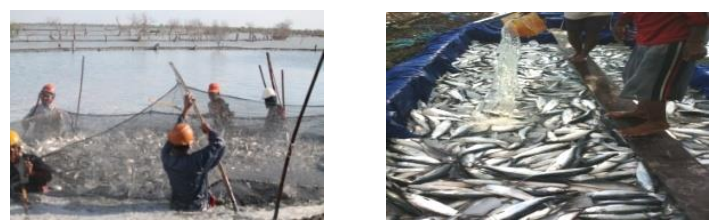

Gambar 1. Dokumentasi Aktivitas Bisnis

Menurut Husnan dan Suwarsosno (1999), analisis sensitivitas adalah memperhitungkan risiko kerugian dengan cara menurunkan atau menaikkan biaya maupun pendapatan dari suatu usaha. Sehingga diketahui tingkat sensitivitas atau kepekaan usaha terhadap perubahan biaya dan atau pendapatan.

Menurut Pudjosumarto (1985), tujuan utama dari analisis sensitivitas adalah:

1. Untuk memperbaiki cara pelaksanaan proyek yang sedang dilaksanakan

2. Untuk memperbaiki design dari proyek, sehingga dapat meningkatkan NPV

3. Untuk mengurangi resiko kerugian dengan menunjukkan beberapa tindakan pencegahan yang harus diambil.

Penelitian ini menggunakan analisis SWOT yang menunjukkan bahwa kinerja bisnis dapat ditentukan oleh kombinasi faktor internal dan eksternal. SWOT adalah singkatandari lingkungan internal Strengths dan Weakness serta lingkungan eksternal Opportunities dan Threats yang dihadapi dunia bisnis (Rangkuti, 2008).

Setelah diidentifikasi dari faktor - faktor strategis internal pada bisnis tambak ikan bandeng, maka tabel IFAS (Internal Strategic Factor Analysis Summary) disusun untuk merumuskan faktor strategis internal dalam kerangka Strenght and Weaknees. Lalu dilakukan penyusunan factor strategi eksternal, langkah yang harus diketahui terlebih dahulu adalah faktor strategi (EFAS) dengan melakukan pembobotan dan skoring untuk merumuskan peluang dan acaman pada bisnis yang dijalankan (Rangkuti, 2008).

Matriks SWOT dapat menggambarkan bagaimana peluang dan ancaman dari lingkungan eksternal perusahaan diantisipasi dengan kekuatan dan kelemahan yang dimilikinya. Matriks SWOT akan mempermudah merumuskan berbagai strategi. Pada dasarnya alternatif strategi yang diambil harus di arahkan pada usaha-usaha untuk menggunakan kekuatan dan memperbaiki kelemahan, memanfaatkan peluang-peluang bisnis serta mengatasi ancaman. Sehingga dari matriks SWOT tersebut akan memperoleh 
empat kelompok alternatif strategi yang disebut strategi SO, strategi ST, strategi WO, dan strategi WT (Fahmi, 2014).

\section{HASIL PENELITIAN DAN PEMBAHASAN \\ Kegiatan Bisnis Tambak Ikan Bandeng}

Usaha pembesaran ikan bandeng ini dilakukan pada tambak tradisional., dimana tambak tersebut dibangun di lahan pasang surut yang berupa rawa - rawa bakau. Luas dari tambak ini sebesar $10 \mathrm{Ha}$ dengan memiliki bentuk dan ukuran petakan yang tidak teratur. Dalam satu unit tambak tersebut terbagi atas dua macam petakan yang terdiri dari petak pendederan dan petak pembesaran. Teknis pembesaran ikan bandeng dimulai dari persiapan tambak, pemupukan dan pemberantasan hama, penyiapan nener, penebaran benih dan pengelolaan tambak, sampai dengan pemanenan telah berjalan dengan baik sehingga menghasilkan ikan bandeng yang berkualitas.

\section{Strategi Pengembangan Bisnis Tambak Ikan Bandeng}

Faktor internal usaha terdiri dari faktor yang menjadi kekuatan dan kelemahan yang mempengaruhi usaha pembesaran ikan bandeng. Faktor yang menjadi kekuatan yaitu ketersediaan sarana dan prasarana, penguasaan teknis dalam usaha pembesaran ikan bandeng, memiliki hubungan yang baik dengan tengkulak, dan usaha layak untuk dijalankan aspek finansiil. Faktor internal kekuatan tersebut dari perhitungan bobot dan rating didapatkan sebesar 1,90.

Faktor internal usaha yang menjadi kelemahan yaitu jumlah tenaga kerja kurang ideal, manajemen usaha masih sederhana, produksi ikan bandeng masih relatif sedikit, dan tidak memiliki pembukuan keuangan usaha. faktor internal kelemahan tersebut dari perhitungan bobot dan rating didapatkan sebesar 1,25.

Faktor eksternal usaha terdiri dari faktor yang menjadi peluang dan ancaman yang mempengaruhi usaha pembesaran ikan bandeng. faktor yang menjadi peluang yaitu permintaan ikan bandeng yang terus meningkat, sumberdaya alam yang mendukung, harga ikan bandeng yang stabil dan dukungan dari instansi dinas kelautan dan perikanan. faktor eksternal peluang tersebut dari perhitungan bobot dan rating didapatkan sebesar 1,50.
Faktor eksternal usaha yang menjadi ancaman yaitu meningkatnya persaingan usaha pembesaran ikan bandeng, serangan hama dan penyakit, dan perubahan cuaca dan iklim tidak menentu. faktor eksternal ancaman tersebut dari perhitungan bobot dan rating didapatkan sebesar 1,15 .

Berdasarkan diagram SWOT didapatkan hasil yaitu berada pada titik $\mathrm{X}=0,65$ dan $\mathrm{Y}=$ 0,35 . Hasil tersebut dapat dilihat pada gambar berikut:

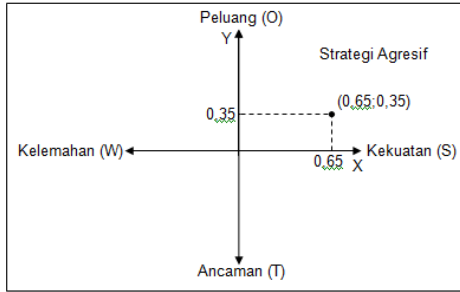

Gambar 2. Diagram Hasil Analisis SWOT Sumber: Hasil Analisis SWOT

Diagram analisis SWOT diketahui bahwa berdasarkan hasil scoring yang dilakukan terhadap faktor - faktor internal dan eksternal diperoleh nilai koordinat yang terletak pada kuadran I. mendukung kebijakan pertumbuhan yang agresif (Growth Oriented Strategy) dengan menggunakan strategi SO (Strength Opportunities) yang diterapkan dengan cara mengoptimalkan kekuatan yang dimiliki usaha serta mampu memanfaatkan peluang yang ada di sekitar usaha pembesaran ikan bandeng di tambak tersebut. Sehingga beberapa strategi yang digunakan yaitu mempertahankan kualitas ikan bandeng, mengadakan pelatihan dengan petugas penyuluh lapang, memanfaatkan sumberdaya alam, sarana dan prasarana untuk mendukung usaha, dan mengoptimalkan usaha ini menjadi lebih baik dengan melihat dari aspek finansiil yang layak.

\section{Perencanaan Pengembangan Bisnis Tambak Ikan Bandeng}

1. Aspek Manajemen

a. Perencanaan (planning)

Perencanaan dilakukan dengan menambah jumlah pembelian nener dan obat-obatan sebesar 10\% dari keadaan faktual. Lokasi yang strategis dan mudah dijangkau oleh konsumen juga salah satu perencanaan yang menguntungkan bagi pemilik usaha.

b. Pengorganisasian (organizing)

Pengorganisasian pada usaha pembesaran ikan bandeng di tambak masih belum terlaksana dengan baik dikarenakan pemimpin sekaligus 
pemilik masih mengerjakan sendiri tanpa adanya karyawan tetap. Dalam hal ini pelaku usaha dibantu oleh 6 orang buruh pada saat persiapan tambak dan pemanenan.

c. Pergerakan (actuating)

Memberikan reward berupa uang dan ikan bandeng hasil pemanenan kepada pekerja yang rajin, agar lebih termotivasi untuk bekerja lebih rajin lagi. Selain itu juga terdapat punishment bagi pekerja yang malas untuk diberhentikan bekerja.

d. Pengawasan (controlling)

Dalam pembukuan keuangan pada bisnis tambak ikan bandeng, tidak ada catatan khusus sehingga kurang bisa mengetahui kondisi keuangan usaha seperti pengeluaran yang dikeluarkan setiap bulannya untuk usaha ini dan apakah usaha tersebut mengalami keuntungan atau kerugian

2. Aspek Pemasaran

a. Permintaan

Perencanaan bisnis pada usaha ini tidak merubah permintaan terhadap ikan bandeng di tambak yang semakin tahun semakin meningkat. Dilihat dari perkembangan setiap siklus pemanenan dan permintaan terhadap ikan bandeng selalu bertambah untuk permintaan daerah lokal maupun luar kota atau luar provinsi. permintaan ikan bandeng yang mengalami peningkatan di setiap tahunnya menjadikan ikan bandeng sebagai konsumsi rumah tangga, pengolahan di pabrik, serta ekspor ke luar negeri.

b. Saluran pemasaran

Saluran pemasaran dalam perencanaan bisnis pada usaha pembesaran ikan bandeng di tambak yaitu pemasaran secara langsung dengan perantara berupa website yang dibuat oleh peneliti. Saluran pemasaran ini memiliki tahapan yang singkat, dimana hanya ada produsen dan konsumen. Saluran pemasaran yang sedemikian rupa merupakan pemasaran yang efisien.

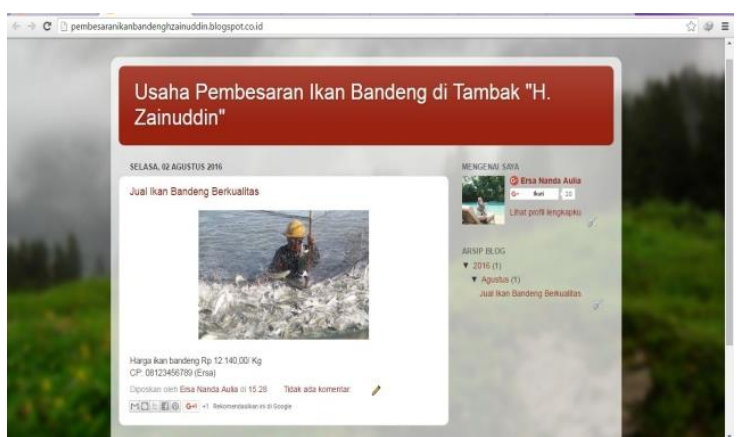

Gambar 3. Website Perencanaan Pembesaran Ikan Bandeng

\section{Aspek Finansiil}

Untuk perencanaan finansiil yaitu dengan cara meningkatkan output dengan menambahkan jumlah nener ikan bandeng dan obat-obatan sebesar $10 \%$, sehingga didapatkan perubahan dari kondisi faktual analisis jangka pendek untuk modal kerja sebesar Rp 9.135.333,00, biaya tidak tetap sebesar Rp 7.322.000,00, biaya total sebesar $\mathrm{Rp}$ 9.135.333,00, penerimaan sebesar $\mathrm{Rp}$ 133.540.000,00/tahun, RC Ratio sebesar 14,6, BEPsales sebesar Rp 1.908.772,00, BEPunit sebesar Rp 158,00/Kg, keuntungan sebesar Rp 124.404.667,00 dan rentabilitas sebesar $1.326 \%$. sedangkan rencana analisis jangka panjang untuk 10 tahun kedepan didapatkan nilai NPV sebesar Rp 577.839.926,00, Net B/C sebesar 149,54, IRR sebesar $3.177 \%$, dan PP sebesar 0,03 tahun.

\section{KESIMPULAN DAN SARAN Kesimpulan}

1. Kondisi faktual yang meliputi aspek teknis yang menghasilkan ikan bandeng dengan kualitas baik; aspek manajemen yang terdiri dari fungsi perencanaan, pengorganisasian, pergerakan dan pengawasan telah berjalan sesuai dengan tujuan bisnis untuk kepuasan konsumen; aspek pemasaran yang terdiri dari bauran pemasaran, saluran pemasaran, margin pemasaran dan sistem pembayaran telah berjalan sesuai dengan target memenuhi kebutuhan konsumen; dan aspek finansiil pada bisnis pembesaran ikan bandeng meliputi analisis jangka pendek dan analisis jangka panjang telah melebihi dari kriteria yang telah ditentukan, sehingga bisnis pembesaran ikan bandeng tersebut layak untuk dijalankan dan menguntungkan.

2. Strategi pengembangan bisnis pembesaran ikan bandeng terletak pada kuadran I, yaitu mendukung kebijakan pertumbuhan yang agresif dengan cara mengoptimalkan kekuatan serta memanfaatkan peluang yang ada di sekitar bisnis. Sehingga beberapa strategi pengembangan bisnis yang digunakan yaitu mempertahankan kualitas ikan bandeng, mengadakan pelatihan dengan petugas penyuluh lapang, memanfaatkan sumberdaya alam, sarana dan prasaran serta mengoptimalkan bisnis dengan melihat dari aspek finansiil yang layak.

3. Perencanaan bisnis pengembangan bisnis pembesaran ikan bandeng pada saluran pemasaran yaitu menggunakan website yang 
telah dibuat oleh peneliti. Sedangkan pada perencanaan finansiil dengan menambahkan jumlah nener ikan bandeng dan obat-obatan sebesar $10 \%$ yang dapat meningkatkan output sehingga perencanaan bisnis pembesaran ikan bandeng lebih banyak memperoleh keuntungan.

\section{Saran}

Berdasarkan arah pengembangan usaha pembesaran ikan bandeng di tambak yaitu mendukung kebijakan pertumbuhan yang agresif (Growth Oriented Strategy) dan menggunakan strategi SO (Strength Opportunities) yang diterapkan dengan cara mengoptimalkan kekuatan dan memanfaatkan peluang yang ada. Namun, usaha pembesaran ikan bandeng masih memiliki kelemahan dan ancaman yang dapat menghambat perkembangan usaha sehingga perlu adanya strategi lain untuk pengembangan usaha.

1. Strategi WO (weakness opportunities)

Strategi dengan memanfaatkan peluang dan meminimalkan kelemahan yang ada. Strategi WO (weakness opportunities) untuk pengembangan usaha yaitu memperbaiki aspek manajemen agar tertata dengan rapi, meningkatkan kapasitas produksi ikan bandeng, melakukan pembukuan keuangan untuk mengetahui perkembangan usaha, dan mengoptimalkan usaha pembesaran sebagai usaha utama

\section{Strategi $S T$ (strength threat)}

Strategi yang menggunakan kekuatan untuk mengatasi mengatasi ancaman. Strategi ST (strength threat) untuk pengembangan usaha yaitu melakukan budidaya pembesaran ikan bandeng saat kondisi cuaca sedang baik untuk menghindari serangan hama dan penyakit pada ikan bandeng dan saling bertukar pendapat dengan pembudidaya lain yang bertujuan untuk mengelola budidaya ikan bandeng yang baik

\section{Strategi WT (weakness threat)}

Strategi dengan meminimalkan kelemahan yang ada serta menghindari ancaman. Strategi WT (weakness threat) untuk pengembangan usaha yaitu meningkatkan tenaga kerja untuk membantu proses pembesaran ikan bandeng

\section{DAFTAR PUSTAKA}

Adi, Sapto. 2011. Analisa Usaha Perikanan Budidaya. Pusat Penyuluhan Kelautan dan Perikanan Badan Pengembangan SDM Kelautan dan
Perikanan Kementrian Kelautan dan Perikanan. Jakarta.

Arif, M. Ichsan. 2008. Perencanaan Bisnis. Bisnismikro.com/?p=76. Diakses

pada tanggal 18 Februari 2018.

Akbar \& Usman. (2009). Metode Penelitian Sosial. Jakarta: Bumi Aksara

Ashari, Rezki. 2012. Analisis Kelayakan Usaha Budidaya Ikan Nila dan Ikan Bandeng di Desa Kanaungan Kecamatan Labakkang Kabupaten Pangkep. Makassar.

Denscombe, Martyn. 2003. The Good Research Guide For Small-Scale Research Projects. Glasgow: Bell \& Bain Ltd.

Fahmi, Irham. 2014. Manajemen Strategis Teori dan Aplikasi. Bandung: Alfabeta.

Hitt, Michael A., Ireland, R. Duane and Hoskisson, Robert E. 2017. Strategic Management: Competitiveness and Globalization. Cengage Learning.

Husnan, S dan Suwarsono. 1999. Studi Kelayakan Proyek. UPP AMP YKPN.

Yogyakarta.

Johan, Suwinto. 2011. Studi Kelayakan Pengembangan Bisnis. Graha Ilmu.

Yogyakarta.

Kasmir dan Jakfar. 2012. Studi Kelayakan Bisnis. Prenada Media. Jakarta.

Maulana, Mochammad Evan Setya. 2008. Analisis Kelayakan Usaha Pembuatan Bandeng Isi Pada BANISI di Kecamatan Soreang, Kabupaten Bandung, Jawa Barat. Institut Pertanian Bogor. Bogor.

Muntalim, Faisol Mas'ud. 2014. Pengembangan Budidaya dan Teknologi Pengolahan Ikan Bandeng (Chanos Chanos Forskal) di Kabupaten Lamongan Guna Meningkatkan Nilai Tambah. Jurnal Eksakta Vol 2 No 1.

Pudjosumarto, Mulyadi. 1985. Evaluasi Proyek. Liberty. Yogyakarta.

Rangka, Nur Ansari dan Asaad, Andi Indra Jaya. 2010. Teknologi Budidaya Ikan Bandeng di Sulawesi Selatan. Balai Riset Perikanan Budidaya Air Payau. Sulawesi Selatan 
Rangkuti, Freddy. 2008. Analisis SWOT

Teknik Membedah Kasus Bisnis. Bpfe-

Yogyakarta.

Soehartono, Irawan. 2011. Metode Penelitian Sosial Suatu Teknik Penelitian Bidang Kesejahteraan Sosial dan Ilmu Sosial Lainnya. PT. Remaja Rosdakarya.

Bandung 